\title{
Growing Minds: The Effect of a School Gardening Program on the Science Achievement of Elementary Students
}

\author{
C.D. Klemmer ${ }^{1}$, T.M. Waliczek², and J.M. Zajicek ${ }^{3}$
}

AdDitional Index words. Texas Essential Knowledge and Skills (TEKS), Texas Assessment of Knowledge and Skills (TAKS)

SumMARY. Science achievement of third, fourth, and fifth grade elementary students was studied using a sample of 647 students from seven elementary schools in Temple, Texas. Students in the experimental group participated in school gardening activities as part of their science curriculum in addition to using traditional classroom-based methods. In contrast, students in the control group were taught science using traditional classroom-based methods only. Students in the experimental group scored significantly higher on the science achievement test compared to the students in the control group. No statistical significance was found between girls and boys in the experimental group, indicating that gardening was equally effective at teaching science for both genders. After separating the data into the grade levels, the garden curriculum was more effective as a teaching method in raising science achievement scores for boys in third and fifth grades, and for girls in the fifth grade compared to traditional classroom-based methods alone.

A $\mathrm{n}$ understanding of science is critical in today's society, which is increasingly technology-driven. People now use science on a daily basis to make decisions on evolving issues and technologies such as air travel, national security, cloning, and genetically modified organisms and their possible incorporation into our food. In order to understand these issues and develop informed opinions, we as a society need to have a basic understanding of the principles of science. Basic science skills are often referred to as science literacy, which can be defined as "the knowledge and understanding of scientific concepts and processes required for personal decision making, participation in civic and cultural affairs, and economic productivity" (National Research Council, 1996). A critical precursor to producing science-literate adults is involving children in doing science when they are young (Loucks-Horsley et al., 1990).

The need for more effective education, and more specifically, science education in the United States has been repeatedly established in

Acknowledgements: The authors express appreciation for the financial support of the Kellogg Foundation.

${ }^{1}$ Director of Education, National Gardening Association, 1100 Dorset St., South Burlington, VT 05403.

${ }^{2}$ Associate Professor, Texas State University, San Marcos, TX 78666

${ }^{3}$ Professor, Department of Horticultural Sciences, Texas A\&M University, College Station, TX 77843-2133. numerous studies. These include A Nation at Risk (National Commission on Excellence in Education, 1983), which calls for the reform of the U.S. education system, and Science for All Americans (American Association for the Advancement of Science, 1990), which defines scientific literacy for high school graduates. Despite the attention that science literacy has received, it and science education in general remain subjects of concern. While students begin elementary school exhibiting spontaneous interest in science and math, they often emerge "fearing mathematics and disdaining science as too dull and too hard to learn" (American Association for the Advancement of Science, 1990). Research indicates that many teachers, as well as students, believe science to be a set of facts and rules with "right" answers, rather than a process of discovery with many possible outcomes (Driver et al., 1996; Poole, $1995)$. Students, in particular, do not see science as connected with society or offering ways to improve peoples' lives, and may regard it as disconnected and removed from their own daily lives (Driver et al., 1996).

Some studies, and much anecdotal evidence, suggest that there is potential for school gardens to enhance the academic curricula of elementary schools, particularly with regards to science concepts (Waliczek et al., 2003). Much of the literature about children's or school gardens consists of garden-based curricula workbooks and activity guides [Hunken, 1994a, 1994b; Kiefer and Kemple, 1998; Moore and Wong, 1997; Texas Agricultural Extension Service (TAEX), 1999a, 1999b], guidelines for working with youth in gardening programs (Eames-Sheavly, 1999) or provides non-technical gardening guidelines or suggested plant lists (Guy et al., 1996; Moore, 1993).

Teachers report that gardening increases students' science scores and improves their overall academic achievement (Braun et al., 1989). A survey conducted by researchers at Virginia Polytechnic Institute assessed teacher interest in school gardening at $87 \%$ of the respondents showing a high level of interest in using horticulture/gardening in the classroom, but felt that they needed supplemental training in order to integrate the garden into their curriculum effectively (Dobbs and Relf, 1998). Numerous articles in journals for teachers advocate gardening as an effective method for fostering authentic learning (Markle, 1991; Provost-Clausing and Jacobsen, 1993), and a web survey by Waliczek et al. (2000) showed a strong interest from parents as well.

While it has been historically accepted that hands-on activities like gardening will promote science achievement (Maclin and Hyland, 1999; Shair, 1999), few studies have focused on gardening being incorporated as a curriculum tool for success in academic endeavors. The purpose of this study was to assess the effectiveness of school gardens for enhancing the science achievement of elementary students in the third, fourth, and fifth grades.

\section{Materials and methods}

InSTRUMENTS. Science achievement test instruments were developed by the principal investigator, teachers, curriculum specialists at Texas A\&M University and in the participating school district, and research committee members. These individuals were familiar with the science TEKS (Texas Essential Knowledge and Skills) at the level of implementation in the schools. The TEKS are comprised of the content that the state education agency uses to define science achievement at each grade level (Texas Education Agency, 2004). These individuals were also familiar with the reading levels and 
cognitive abilities of students in the third, fourth, and fifth grades. Their goal was to develop instruments that were grade-appropriate to assess the effectiveness of the curriculum on student achievement in science, based on the science curriculum standards in Texas (Klemmer et al., 2005).

GARDEN CURRICULUM AND TEACHER TRAINING. All schools received copies of a school gardening curriculum including youth handbooks for each student participating, and teacher/leader guides for each teacher participating (TAEX, 1999a, 1999b). The gardening curriculum is based on a similar adult gardening curriculum conducted by state extension agencies throughout the U.S., and is intended to educate youth about horticulture, health, nutrition, environmental science, and leadership. The intent of the gardening curriculum is to offer a hands-on, fun approach to learning horticulture and environmental education while also cultivating community service, leadership and life skills among participating youth (TAEX, 1999a, $1999 \mathrm{~b})$. The curriculum is divided into levels targeting different age groups. Level I of the program was used for this study and is targeted to third through fifth grade students.

Experimental groups received the curriculum materials at the inception of the study. Control groups received curriculum materials at the end of the school year, following the conclusion of the study to compensate them for participating in the study. A full-day school garden training program was held with the participating school district at the beginning of the 200001 school year. The training program was coordinated and run by TAEX employees who specialize in the garden curriculum program, as well as graduate students involved in the Growing Minds research program at Texas A\&M University Department of Horticulture. The training session included a program orientation session, a curriculum overview session, and multiple opportunities to trial activities from the curriculum. All teachers in the district were eligible and encouraged to participate. Those teachers who were unable to attend the training session received materials and training information from other teachers that did attend the training.

Teachers volunteering their classes for participation in the experimental group were asked to incorporate the program into their curriculum to the fullest extent possible, as they would for any new teaching method being adopted by the school district, throughout the entire school term during the 2000-01 school year. In addition, teachers were encouraged to implement outside school gardens or similar small scale indoor plant activities, and complete enough garden activities for students to become certified by the garden curriculum program.

SAMPLE. The sample for this study included classes of third, fourth, and fifth grade students in the Temple Independent School District (ISD) in central Texas. Demographic information, including socioeconomic status

and ethnicity, was obtained from the Temple ISD main office and varied from school to school. School and class selection and assignment to the experimental or control group was coordinated within the school district by the Math and Science Curriculum Coordinator, who wanted to make the program available to as many students as possible due to its perceived benefits. Teachers from each of the schools within the school district volunteered their classes to participate in the study. The final sample consisted of a total of 647 students from seven different schools, with 27 classes and 453 students in the experimental group, and 13 classes and 194 students in the control group (Tables 1-2).

Table 1. Demographic breakdown of the experimental and control groups of students involved in the study of science achievement and school gardening.

\begin{tabular}{|c|c|c|c|c|c|c|}
\hline Group & $\begin{array}{c}\text { Females } \\
\text { (no.) }\end{array}$ & $\begin{array}{c}\text { Female } \\
\text { sample } \\
(\%)\end{array}$ & $\begin{array}{c}\text { Males } \\
\text { (no.) }\end{array}$ & $\begin{array}{c}\text { Male } \\
\text { sample } \\
(\%)\end{array}$ & $\begin{array}{c}\text { Overall } \\
\text { sample } \\
\text { (no.) }\end{array}$ & $\begin{array}{c}\text { Overall } \\
\text { sample }^{\mathrm{z}} \\
(\%)\end{array}$ \\
\hline \multicolumn{7}{|c|}{ Experimental group } \\
\hline Third grade & 44 & $6.8 \%$ & 42 & $6.5 \%$ & 86 & $13.3 \%$ \\
\hline Fourth grade & 111 & $17.2 \%$ & 85 & $13.1 \%$ & 196 & $30.3 \%$ \\
\hline Fifth grade & 81 & $12.5 \%$ & 85 & $13.1 \%$ & 166 & $25.6 \%$ \\
\hline Sub-total & 236 & $36.5 \%$ & 212 & $32.7 \%$ & 448 & $69.2 \%$ \\
\hline \multicolumn{7}{|l|}{ Control group } \\
\hline Third grade & 41 & $6.3 \%$ & 34 & $5.3 \%$ & 75 & $11.6 \%$ \\
\hline Fourth grade & 31 & $4.8 \%$ & 22 & $3.4 \%$ & 53 & $8.2 \%$ \\
\hline Fifth grade & 28 & $4.3 \%$ & 33 & $5.1 \%$ & 61 & $9.4 \%$ \\
\hline Sub-total & 100 & $15.4 \%$ & 89 & $13.8 \%$ & 189 & $29.2 \%$ \\
\hline Totals & 336 & $51.9 \%$ & 301 & $46.5 \%$ & 637 & $98.4 \%$ \\
\hline
\end{tabular}

${ }^{2}$ Ten students or $1.6 \%$ of sample did not complete the demographic portion of test instrument.

Table 2. Summary of elementary schools participating in the study of science achievement using school gardening, including school name, grade levels participating, number of classes and students from each school, and their treatment group placement.

\begin{tabular}{lcccc}
\hline $\begin{array}{l}\text { Elementary } \\
\text { school }\end{array}$ & $\begin{array}{c}\text { Grade } \\
\text { level }\end{array}$ & $\begin{array}{c}\text { Classes from } \\
\text { school (no.) }\end{array}$ & $\begin{array}{c}\text { Students } \\
\text { (no.) }\end{array}$ & $\begin{array}{c}\text { Treatment } \\
\text { group }^{\mathbf{z}}\end{array}$ \\
\hline Cater & 3 & 1 & 19 & $\mathrm{E}$ \\
Garcia & 4 & 3 & 48 & $\mathrm{E}$ \\
Jefferson & 3 & 3 & 52 & $\mathrm{E}$ \\
Jefferson & 4 & 4 & 57 & $\mathrm{E}$ \\
Jefferson & 5 & 3 & 55 & $\mathrm{E}$ \\
Meredith Dunbar & 3 & 5 & 79 & $\mathrm{C}$ \\
Meredith Dunbar & 5 & 6 & 111 & $\mathrm{E}$ \\
Raye-Allen & 4 & 3 & 41 & $\mathrm{E}$ \\
Raye-Allen & 5 & 4 & 63 & $\mathrm{C}$ \\
Scott & 4 & 3 & 54 & $\mathrm{E}$ \\
Western Hills & 3 & 1 & 15 & $\mathrm{E}$ \\
Western Hills & 4 & 4 & 53 & $\mathrm{C}$ \\
Group totals: & & & \\
$\mathrm{n}=7$ schools, 40 classes, 647 students & & \\
$\mathrm{E}=27$ classes, 453 students & & \\
$\mathrm{C}=13$ classes, 194 students &
\end{tabular}


Research Design. The study followed a posttest only quasi-experimental design. Students in classes that incorporated the school gardening program into their science curriculum during the school year comprised the experimental group of the sample. Students in classes receiving science instruction only through traditional methods comprised the control group of the sample. Since all of the classes were subject to the same TEKS curriculum guidelines, students should have been exposed to similar types of content material throughout the school year. However, the experimental group used hands-on garden activities to learn science concepts instead of traditional curriculum methods. At the end of the school year, at approximately the same time, all students included in the experimental and control groups took the grade-appropriate cognitive test for science achievement developed for this study (Klemmer et al., 2005). Teachers administered all exams based on the exam administration criteria for the school district.

Data collection. Tests were coded for student confidentiality and distributed by school faculty to the students during science class. The researcher collected the completed tests from each site.

Scoring Procedure. The demographic surveys and the cognitive test instruments for each student were scanned and scored using Remark Office OMR 4.0 (Principia Products, Paoli, Pa.). Students received a raw score on the test instrument ranging from 0 to 40 based on their answers, with each correct answer receiving one point. For the purposes of analysis and discussion, these raw scores were converted to a 100-point scale. The tabulated scores were then analyzed using SPSS (version 10.0 for Windows95; SPSS, Chicago). Test instruments for each grade were analyzed to determine reliability estimates. Mean scores were then analyzed using analysis of variance (ANOVA) methods to compare scores.

\section{Results and discussion}

Of the 647 students tested, only $10(1.6 \%)$ did not complete the demographic survey. Of the remaining students, $51.9 \%$ were female and $46.5 \%$ were male. Within each grade level subgroup, females and males were balanced except for the fourth grade

Table 3. An analysis of variance comparing mean student science achievement scores $^{\mathrm{z}}$ of experimental and control groups in the study of science achievement and school gardening.

\begin{tabular}{lcccccc}
\hline Group & $\begin{array}{c}\text { Sample } \\
\text { size (no.) }\end{array}$ & $\begin{array}{c}\text { Mean science } \\
\text { scores }^{\mathbf{z}}\end{array}$ & sD & df & F & $\boldsymbol{P}$ \\
\hline Experimental & 454 & 53.07 & 20.374 & 1 & 12.081 & $0.001^{*}$ \\
Control & 193 & 47.41 & 19.105 & & & \\
\hline
\end{tabular}

${ }^{\text {z}}$ Students received a raw score on the test instrument ranging from 0 to 40 based on their answers with each correct answer receiving one point. For the purposes of analysis and discussion, these raw scores were converted to a 100 -point scale.

*Significant at $P \leq 0.05$.

Table 4. An analysis of variance comparing mean student science achievement scores ${ }^{\mathrm{z}}$ within different grade levels of experimental group and control group in the study of science achievement and school gardening.

\begin{tabular}{|c|c|c|c|c|c|c|c|}
\hline $\begin{array}{l}\text { Grade } \\
\text { level }\end{array}$ & Group & $\begin{array}{c}\text { Sample } \\
\text { size (no.) }\end{array}$ & $\begin{array}{c}\text { Mean science } \\
\text { scores }^{\mathrm{z}}\end{array}$ & SD & df & F & $P$ \\
\hline \multirow[t]{2}{*}{3} & Experimental & 88 & 47.84 & 14.91 & 1 & 1.431 & 0.233 \\
\hline & Control & 77 & 45.00 & 15.61 & & & \\
\hline \multirow[t]{2}{*}{4} & Experimental & 200 & 49.16 & 15.60 & 1 & 2.699 & 0.102 \\
\hline & Control & 53 & 53.07 & 14.54 & & & \\
\hline \multirow[t]{2}{*}{5} & Experimental & 166 & 60.54 & 25.28 & 1 & 19.755 & $0.000^{*}$ \\
\hline & Control & 63 & 45.60 & 13.81 & & & \\
\hline
\end{tabular}

${ }^{\mathrm{z}}$ Students received a raw score on the test instrument ranging from 0 to 40 based on their answers with each correct answer receiving one point. For the purposes of analysis and discussion, these raw scores were converted to a 100 -point scale.

*Significant at $P \leq 0.05$.

experimental group, which had slightly more females $(17.2 \%)$ than males (13.1\%) (Table 1). Reliability analyses for the overall test instrument yielded a Cronbach's alpha of 0.86 (Klemmer et al., 2005).

EXPERIMENTAL vs. CONTROL Group. A one-way ANOVA was conducted to test the statistical difference of the means between the experimental and control groups (Table 3 ). Students in the experimental group scored 5.6 points higher on the science achievement test compared to the students in the control group. This improvement in score was statistically significant $(P$ $=0.001)$. These findings indicate that students who participated in hands-on gardening activities had higher science achievement scores versus those who did not. This is in accord with research indicating that students' knowledge levels are increased through the use of hands-on, experiential activities (Freedman, 1997; Johnson et al., 1998; Keeves and Morganstern, 1992; Solter, 1997; Stohr-Hunt, 1996;Zimmerman et al., 1998).

Demographic DifFerences. In order to detect differences among variables at a more detailed level, additional ANOVA tests were conducted. Results indicated that fifth grade students who participated in gardening activities as part of their science education scored 14.9 points higher compared to students in the control group, which was statistically significant $(P=0.000)$ (Table 4$)$. Differences in science achievement scores were not significantly different between experimental and control groups in the other two grade levels (Table 4).

This suggests that students in the fifth grade benefited more from the hands-on gardening program than students in the lower grade levels. One explanation for this finding may be that students in the higher grade level were more developmentally advanced with regard to cognitive skills in science, and were therefore better able to learn, apply and relate concepts taught during the hands-on gardening program to general science concepts being taught at that grade level.

Male vs. Female STUdent COMPARISONS. In order to determine if boys and girls are influenced differently by the incorporation of a gardening program into their science curriculum, several different comparisons were made. A two-way ANOVA was conducted to determine whether there was a statistically significant difference between mean scores of female and male students in the experimental group, and between mean scores of female and male students in the control group (Table 5). Statistical significance was 
found between mean scores of females and males in the control group $(P=$ $0.027)$. While there was a difference between the mean scores of females and males in the experimental group, the finding was not statistically significant. This indicates that the experimental treatment of hands-on gardening did not discriminate between females and males. Rather, both groups benefited from the gardening activities. In the control group, the finding of statistical significance indicates that one of the genders gained more benefit from the traditional studies than did the other. The higher mean score for females (49.75) suggests that females were favored over males (mean score $=44.89$ ) in the control group where traditional classroom-based methods were used.

WITHIN GENDER COMPARISONS. To provide additional insight into the effect of the gardening treatment within gender, a two-way ANOVA was conducted (Table 6). Statistically significant differences indicated that, for both genders, there was a differential effect between the control and experimental groups. Mean student scores for females in the experimental group were 4.31 points higher compared to females in the control group and 7.37 points higher for males in the experimental group compared to males in the control group. The science achievement of students participating in a hands-on school gardening program was higher than that of students participating in traditional classroom-based methods, regardless of gender, although the effect was more evident for males.

EXPERIMENTAL VS. CONTROL GROUP WITHIN GENDER BY GRADE LEVEL. Additional analysis was conducted using a three-way univariate ANOVA to determine which grade levels exhibited within-gender differences (Table 7). Positive statistical significance was found between experimental and control group males in third and fifth grade levels $(P=0.050$ and $P=$ 0.001 , respectively), and between experimental and control group females in the fifth grade $(P=0.012)$. Fourth grade females showed no differences in experimental and control group comparisons, while results for males in the fourth grade indicated negative statistical significance $(P=0.041)$ with the control group performing better on the science achievement instrument. With the exception of students in the

Table 5. Two-way analysis of variance comparing mean science achievement scores $^{\mathrm{z}}$ of females and males within experimental vs. control groups in the study of science achievement and school gardening.

\begin{tabular}{llcccccc}
\hline Group & Gender & $\begin{array}{c}\text { Sample } \\
\text { size (no.) }\end{array}$ & $\begin{array}{c}\text { Mean science } \\
\text { scores }^{z}\end{array}$ & SD & df & F & $\boldsymbol{P}$ \\
\hline Experimental & Female & 236 & 54.06 & 19.63 & 1 & 0.866 & 0.353 \\
& Male & 212 & 52.26 & 21.15 & & & \\
Control & Female & 100 & 49.75 & 14.07 & 1 & 4.967 & $0.027^{\star}$ \\
& Male & 89 & 44.89 & 15.92 & & & \\
\hline
\end{tabular}

${ }^{2}$ Students received a raw score on the test instrument ranging from 0 to 40 based on their answers with each correct answer receiving one point. For the purposes of analysis and discussion, these raw scores were converted to a 100 -point scale.

"Significant at $P \leq 0.05$

Table 6. Two-way analysis of variance comparing effects of experimental vs. control groups within gender in the study of science achievement and school gardening.

\begin{tabular}{llcccccc}
\hline Group & Gender & $\begin{array}{c}\text { Sample } \\
\text { size (no.) }\end{array}$ & $\begin{array}{c}\text { Mean science } \\
\text { scores }^{\text {z }}\end{array}$ & SD & df & F & $P$ \\
\hline \multirow{2}{*}{ Female } & Experimental & 236 & 54.06 & 19.63 & 1 & 3.950 & $0.048^{*}$ \\
& Control & 100 & 49.75 & 14.07 & & & \\
Male & Experimental & 212 & 52.26 & 21.15 & 1 & 8.738 & $0.003^{*}$ \\
& Control & 89 & 44.89 & 15.92 & & & \\
\hline
\end{tabular}

${ }^{2}$ Students received a raw score on the test instrument ranging from 0 to 40 based on their answers with each correct answer receiving one point. For the purposes of analysis and discussion, these raw scores were converted to a 100 -point scale.

"Significant at $P \leq 0.05$

Table 7. Three-way univariate analysis of variance comparing within-gender effects in each grade level in the study of science achievement and school gardening.

\begin{tabular}{|c|c|c|c|c|c|c|c|c|}
\hline $\begin{array}{l}\text { Grade } \\
\text { level }\end{array}$ & Gender & Group & $\begin{array}{c}\text { Sample } \\
\text { size (no.) }\end{array}$ & $\begin{array}{c}\text { Mean science } \\
\text { scores }^{\mathrm{z}}\end{array}$ & SD & df & $\mathbf{F}$ & $P$ \\
\hline \multirow[t]{4}{*}{3} & \multirow[t]{2}{*}{ Female } & Experimental & 44 & 51.14 & 15.72 & \multirow[t]{2}{*}{1} & \multirow[t]{2}{*}{0.081} & \multirow[t]{2}{*}{0.776} \\
\hline & & Control & 41 & 50.18 & 15.09 & & & \\
\hline & \multirow{2}{*}{ Male } & Experimental & 42 & 44.64 & 12.75 & \multirow[t]{2}{*}{1} & \multirow[t]{2}{*}{3.964} & \multirow{2}{*}{$0.050^{*}$} \\
\hline & & Control & 31 & 38.53 & 13.97 & & & \\
\hline \multirow[t]{4}{*}{4} & \multirow{2}{*}{ Female } & Experimental & 111 & 51.04 & 15.03 & \multirow[t]{2}{*}{1} & \multirow[t]{2}{*}{0.049} & \multirow[t]{2}{*}{0.826} \\
\hline & & Control & 31 & 51.69 & 13.30 & & & \\
\hline & \multirow[t]{2}{*}{ Male } & Experimental & 85 & 47.03 & 16.11 & \multirow[t]{2}{*}{1} & \multirow[t]{2}{*}{4.262} & \multirow[t]{2}{*}{$0.041^{*}$} \\
\hline & & Control & 22 & 55.00 & 16.26 & & & \\
\hline \multirow[t]{4}{*}{5} & \multirow[t]{2}{*}{ Female } & Experimental & 81 & 59.78 & 25.26 & \multirow[t]{2}{*}{1} & \multirow[t]{2}{*}{6.545} & \multirow[t]{2}{*}{$0.012^{*}$} \\
\hline & & Control & 28 & 46.96 & 13.51 & & & \\
\hline & \multirow[t]{2}{*}{ Male } & Experimental & 85 & 61.26 & 25.42 & \multirow[t]{2}{*}{1} & \multirow[t]{2}{*}{12.415} & \multirow[t]{2}{*}{$0.001^{*}$} \\
\hline & & Control & 33 & 44.70 & 14.47 & & & \\
\hline
\end{tabular}

${ }^{2}$ Students received a raw score on the test instrument ranging from 0 to 40 based on their answers with each correct answer receiving one point. For the purposes of analysis and discussion, these raw scores were converted to a 100 -point scale by multiplying them by a factor of 2.5 .

*Significant at $P \leq 0.05$

fourth grade, these results are similar to the previously mentioned results with positive effects of the gardening program on males and fifth grade students.

\section{Conclusions}

The elementary grades are an especially critical time in the development of an interest, or disinterest, in science (Shapiro, 1994). A critical precursor to producing science literate adults is actively involving kids in experiential science activities when they are young
(Loucks-Horsley et al., 1990). Previous studies have shown the importance of hands-on learning in promoting positive attitudes toward science (Eisenhardt, 1977; Fleming and Malone, 1983; Keeves and Morganstern, 1992; Kyle et al., 1988; Zimmerman et al., 1998), and have shown evidence of students functioning at higher levels of learning including the ability to analyze, synthesize and evaluate problems (Bloom et al., 1956; Waliczek et al., 2003).

Agricultural disciplines have 
special application with regards to active learning to increase science achievement and science literacy. When agricultural science disciplines were used as a basis for teaching curricular concepts, they have been found to increase scores on cognitive science tests (Johnson et al., 1998) and science process skills (Mabie and Baker, 1996), as well as students' comprehension of science process skills and increased excitement in doing "real" science (Solter, 1997).

School gardens offer one area of agriscience through which schools can provide opportunities for studentcentered, experiential learning. The results of this study showed that the science achievement of students who participated in a hands-on school gardening program was higher than that of students who did not participate in gardening activities as part of their science curriculum. Hands-on, constructivist learning serves as the main idea behind school garden programs. Gardens can serve as living laboratories in which students can see what they are learning and in turn, apply that knowledge to real world situations (Adams and Hamm, 1998).

\section{Literature cited}

Adams, D. and M. Hamm. 1998. Collaborative inquiry in science, math, and technology. Heinemann, Portsmouth, N.H.

American Association for the Advancement of Science. 1990. Project 2061: Science for all Americans. Oxford Univ. Press, New York.

Bloom, B., M. Englehart, E. Furst, W. Hill, and D. Krathwohl. 1956. Taxonomy of educational objectives: The classification of educational goals. Hdbk. I: Cognitive domain. Longmans Green, New York.

Braun, J., M. Kotar, and J. Irick. 1989. Cultivating and integrated curriculum: The school garden. Social Studies Young Learner $1(3): 19-22$.

Dobbs, K. and D. Relf. 1998. A survey of teachers regarding school garden programs in Virginia. HortTechnology 37(3):97-98.

Driver, R., J. Leach, R. Millar, and P. Scott. 1996. Young people's images of science. Open Univ. Press, Buckingham, U.K.

Eames-Sheavly, M. 1999. Sowing the seeds of success: How to start and sustain a kids' gardening project in your community. Natl. Gardening Assn., Burlington, Vt.

Eisenhardt, W.B. 1977. A search for the predominant causal sequence in the interrelationship of interest in academic subjects and academic achievement: A cross-lagged panel correlation study. PhD Diss., Duke Univ., Durham, S.C. Diss. Abstr. Intl., 37, 4225A.

Fleming, M.L. and M.R. Malone. 1983. The relationship of students characteristics and students performance in science as viewed by meta-analysis research. J. Res. Sci. Teaching 20:481-495

Freedman, M. 1997. Relationship among laboratory instruction, attitude toward science, and achievement in science knowledge. J. Res. Sci. Teaching 34(4):343-357.

Guy, L.A., C. Cromell, and L. Bradley. 1996. Success with school gardens. Arizona Master Gardener Press, Phoenix.

Hunken, J. 1994a. Ecology for all ages: Discovering nature through activities for children and adults, 2nd ed. Globe Pequot, Guilford, Conn.

Hunken, J. 1994b. Botany for all ages: Discovering nature through activities for children and adults, 2nd ed. Globe Pequot, Guilford, Conn.

Johnson, D., G.W. Wardlow, and T.D. Franklin. 1998. Method of reinforcement and student gender effects on achievement in agriscience education. J. Agr. Educ. 39(4):18-27.

Keeves, J.P. and C. Morganstern. 1992. Attitudes towards science: Measures and effects, p.122-140. In: J.P. Keeves (ed.). The IEA study of science III: Changes in science education and achievement: 1970-1984. Pergamon, New York.

Kiefer, J. and M. Kemple. 1998. Digging deeper: Integrating youth gardens into schools and communities. Common Roots Press, Montpelier, Vt.

Klemmer, C. D., T.M. Waliczek, and J. M. Zajicek. 2005. The development of a science achievement evaluation instrument for a school garden program, HortTechnology 15(3): (HORTTECH-00178).

Kyle, W., R. Bonnstetter, and T. Gadsen. 1988. An implementation study: An analysis of elementary students' and teachers' attitudes toward science in process approach vs. traditional science classes. J. Res. Sci. Teaching 25(2):103-120.

Loucks-Horsley, S., R. Kapitan, M. Carlson, P. Kuerbis, R. Clark, G.M. Melle, T. Sachse, and W. Walton. 1990. Elementary school science for the '90s. The Network, Inc., Andover, Mass.

Mabie, R. and M. Baker. 1996. A comparison of experiential instructional strategies upon the science process skills of urban elementary students. J. Agr. Educ. 37(2):1-7.

Maclin, T. and B. Hyland. 1999. A lasting harvest. Public Garden 99(14):12-14.

Markle, S. 1991. Green growers: Study soil, seeds, and sprouts, and learn how to grow a great garden. Instructor Mar. 1991.
Moore, R. 1993. Plants for play. MIG Commun., Berkeley, Calif.

Moore, R. and H. Wong. 1997. Natural learning: The life history of an environmental schoolyard. MIG Commun., Berkeley, Calif.

National Research Council. 1996. Inquiry and the national science education standards. Natl. Academy Press, Washington, D.C.

National Commission on Excellence in Education. 1983. A nation at risk: The imperative for educational reform. U.S. Dept. of Educ., Washington, D.C.

Poole, M. 1995. Beliefs and values in science education. Open Univ. Press, Buckingham, U.K.

Provost-Clausing, R. and P. Jacobsen. 1993. How does your garden grow? Instructor Sept. 1993.

Shapiro, B. 1994. What children bring to light: A constructivist perspective on children's learning in science. Teachers College Press, New York.

Shair, G. 1999. A history of children's gardens. Public Garden 99(14):9-11.

Solter, L. 1997. Is entomological research child's play? Teaching children scientific methods. Amer. Entomol. 4:198-200.

Stohr-Hunt, P. 1996. An analysis of frequency of hands-on experience and science achievement. J. Res. Science Teaching 33(1):101-109.

Texas Agricultural Extension Service. 1999a. Junior Master Gardener handbook, Level 1. Agr. Commun., Texas A\&M Univ., College Station.

Texas Agricultural Extension Service. 1999b. Junior Master Gardener teacher/leader guide, Level 1. Agr. Commun., Texas A\&M Univ., College Station.

Texas Education Agency. 2004. Texas Essential Knowledge and Skills (TEKS). Texas Education Agency, Austin. 13 June 2004. <http://www.tea.state.tx.us/teks/>.

Waliczek, T.M., J.C. Bradley, R.D. Lineberger, and J.M. Zajicek. 2000. Using a web-based survey to research the benefits of children's gardening. Hort Technology 10(1):71-76.

Waliczek, T.M., P. Logan, and J.M. Zajicek. 2003. Exploring the impact of outdoor environmental activities on children using a qualitative text data analysis system. HortTechnology 13(4):684-688.

Zimmerman, C., G.L. Bisanz, and J. Bisanz. 1998. Everyday scientific literacy: Do students use information about the social context and methods of research to evaluate news briefs about science? Alberta J. Educ. Res. 44(2):188-207. 